\title{
Designing Lesson Plan Based on Critical Thinking for Language Classes
}

\author{
Norwanto \\ English Department of Educational Faculty \\ State Islamic Studies Institute (STAIN) Salatiga \\ Jl. Tentara Pelajar No.2 Salatiga, Central Java, Indonesia \\ norwanto@yahoo.com
}

\begin{abstract}
Critical thinking includes a process of reasoning in thinking as stated by some scholars. In the process, there is universal standard to follow: clarity, accuracy, precision, relevance, depth, breadth, logic, and fairness. In language classes, critical thinking creates active classes. To bring critical thinking to classes, Bloom's Taxonomy and critical thinking strategies can be working definition in order critical thinking to be applied to pedagogical materials in a practical way. Steps for critical thinking teaching includes five steps: (1) determining learning objectives, (2) teaching through questioning, (3) practicing before assessing, (4) reviewing, refining, and improving, and (5) providing feedback and assessment of learning. A lesson plan should reflect these five steps.
\end{abstract}

Keywords: Critical Thinking, Language Teaching, Lesson Plan, Bloom's Taxonomy, Critical Thinking Strategies

\begin{abstract}
Abstrak
Berpikir kritis mencakup proses penalaran dalam berpikir seperti yang dinyatakan oleh beberapa ahli. Dalam prosesnya, ada standar universal untuk diikuti: kejelasan, akurasi, presisi, relevansi, kedalaman, keluasan, logika, dan kewajaran. Di kelas bahasa sendiri, berpikir kritis dapat menciptakan kelas yang aktif. Untuk membawa pemikiran kritis ke dalam kelas, taksonomi Bloom dan strategi berpikir kritis dapat menjadi metode yang tepat agar berpikir kritis dapat diterapkan pada materi pedagogis dengan cara yang praktis. Langkah-langkah untuk mengajarkan berpikir kritis meliputi lima langkah: (1) menentukan tujuan pembelajaran, (2) pengajaran melalui pertanyaan, (3) berlatih sebelum menilai, (4) meninjau, menyaring, dan meningkatkan, dan (5) memberikan umpan balik dan penilaian pembelajaran. Sebuah rencana pembelajaran harus mencerminkan lima langkah tersebut.
\end{abstract}


Kata Kunci : Berpikir Kritis, Pengajaran Bahasa, RPP, Taksonomi Bloom, Strategi Berpikir Kritis

\section{Introduction}

There are many definitions of critical thinking. Moore and Parker (2009: 3) define critical thinking as "the careful application of reason in the determination of whether a claim is true". Robert Ennis (in Hunter, 2009) states that critical thinking is "reasonable, reflective thinking that is aimed at deciding what to believe or what to do". The two definitions emphasize critical thinking on reason. Meanwhile, Gieve (1998 in Rear, 2010) gives some requirements for students to think critically. They must be able to "examine the reasons for their actions, their beliefs, and their knowledge claims, requiring them to defend themselves and question themselves, their peers, their teachers, experts, and authoritative texts".

In critical thinking, there is universal intellectual standard which must be applied to thinking as the assessment of thinking. The standard comprises clarity, accuracy, precision, relevance, depth, breadth, logic, and fairness (Paul and Elder, 2010). Each part of the standard has some questions that may help self assessment for thinking. In classes, teacher may pose these questions in order to help students critically. Paul and Elder (2010) proposes the questions in the table:

\begin{tabular}{|l|l|}
\hline \multicolumn{1}{|c|}{ Standard } & \multicolumn{1}{|c|}{ Questions } \\
\hline Clarity & $\begin{array}{l}\text { Could you elaborate further on that point? Could } \\
\text { you express that point in another way? Could you } \\
\text { give me an illustration? Could you give me an } \\
\text { example? }\end{array}$ \\
\hline
\end{tabular}




\begin{tabular}{|l|l|}
\hline Accuracy & $\begin{array}{l}\text { Is that really true? How could we check that? How } \\
\text { could we find out if that is true? }\end{array}$ \\
\hline Precision & $\begin{array}{l}\text { Could you give more details? Could you be more } \\
\text { specific? }\end{array}$ \\
\hline Relevance & $\begin{array}{l}\text { How is that connected to the question? How does } \\
\text { that bear on the issue? }\end{array}$ \\
\hline Depth & $\begin{array}{l}\text { How does your answer address the complexities in } \\
\text { the question? How are you taking into account the } \\
\text { problems in the question? Is that dealing with the } \\
\text { most significant factors? }\end{array}$ \\
\hline Breadth & $\begin{array}{l}\text { Do we need to consider another point of view? Is } \\
\text { there another way to look at this question? What } \\
\text { would this look like from a conservative } \\
\text { standpoint? What would this look like from the } \\
\text { point of view of . .? }\end{array}$ \\
\hline Logic & $\begin{array}{l}\text { Does this really make sense? Does that follow from } \\
\text { what you said? How does that follow? But before } \\
\text { you implied this, and now you are saying that; how } \\
\text { can both be true? }\end{array}$ \\
\hline Fairness & $\begin{array}{l}\text { Do I have a vested interest in this issue? Am I } \\
\text { sympathetically representing the viewpoints of } \\
\text { others? }\end{array}$ \\
\hline
\end{tabular}

Critical thinking can be also incorporated into language classes. Car (1990), for example, proposes the use of news media in the class. Comparing differing accounts and editorials may help students read with questioning attitude. Critical reading, then, has been defined as learning to evaluate, draw inferences and arrive at conclusions based on the evidence (Zintz and Maggart, 1984 in Carr, 1990). Meanwhile, for writing, Elbow (1983: in Carr, 1990) has presented first order and second-order thinking. For first order thinking, he proposes free writing that will produces conceptual insight. 


\section{Discussion}

To bring critical thinking to classes, working definition is important in order critical thinking to be applied to pedagogical materials in a practical way (Rear, 2010). Fortunately, Bloom's Taxonomy and critical thinking strategy can be the bridge between critical thinking and classes.

\section{Bloom's taxonomy}

Banjamin Bloom (1956) identifies three domain of educational activities: cognitive, affective, and psychomotor (in Clark, 2004). Each domain has some major categories. Clark (2004) summarizes the three domain and its categories.

Cognitive domain has six categories. The first is knowledge or the lowest ability to recall data or information. The second is Comprehension which means the learners ability to understand the meaning, translation, interpolation, and interpretation of instructions and problems. The third is application, the ability to use a concept in a new situation or unprompted use of an abstraction; Applies what was learned in the classroom into novel situations in the work place. The next higher level, the fourth, is analysis. In this category, students or learners are expected to be able to separates material or concepts into component parts, so that its organizational structure may be understood; distinguishes between facts and inferences. The fifth is synthesis, how to builds a structure or pattern from diverse elements; put parts together to form a whole, with emphasis on creating a new meaning or structure. And the last is evaluation or to make judgments about the value of ideas or materials.

The next domain is affective which has five categories. The first requires students to have awareness, willingness to hear, selected attention. 
This category is usually called as receiving phenomena. The second is responding to phenomena. In this category, students must be active participation on the part of the learners, attends and reacts to a particular phenomenon and learning outcomes may emphasize compliance in responding, willingness to respond, or satisfaction in responding (motivation). The third is valuing or the worth or value a person attaches to a particular object, phenomenon, or behavior. This ranges from simple acceptance to the more complex state of commitment. Valuing is based on the internalization of a set of specified values, while clues to these values are expressed in the learner's overt behavior and are often identifiable. The fourth is Organization or students or learners must be able to organize values into priorities by contrasting different values, resolving conflicts between them, and creating an unique value system. The emphasis is on comparing, relating, and synthesizing values. The last is internalizing values (characterization). Students have a value system that controls their behavior. The behavior is pervasive, consistent, predictable, and most importantly, characteristic of the learner. Instructional objectives are concerned with the student's general patterns of adjustment (personal, social, emotional).

\section{Critical thinking strategy}

Paul, Binker, and Weil (1995) write 35 aspects or instructional strategies. These strategies are in three categories: affective strategies, cognitive strategies - micro abilities, and cognitive strategies - micro abilities. Affective strategies includes strategy 1 (S-1) until strategy 9 (S-9): S-1 thinking independently, S-2 developing insight into egocentricity or sociocentricity, S-3 exercising fairmindedness, S-4 exploring thoughts underlying feelings and feelings underlying thoughts, S-5 developing intellectual humility and suspending judgment, S-6 developing intellectual 
courage, S-7 developing intellectual good faith or integrity, S-8 developing intellectual perseverance, S-9 developing confidence in reason

Cognitive Strategies - Macro-Abilities has 17 strategies. They are: S-10 refining generalizations and avoiding oversimplifications, S-11 comparing analogous situations: transferring insights to new contexts, S-12 developing one's perspective: creating or exploring beliefs, arguments, or theories, S-13 clarifying issues, conclusions, or beliefs, S-14 clarifying and analyzing the meanings of words or phrases, S-15 developing criteria for evaluation: clarifying values and standards, S-16 evaluating the credibility of sources of information, S-17 questioning deeply: raising and pursuing root or significant questions, S-18 analyzing or evaluating arguments, interpretations, beliefs, or theories, S-19 generating or assessing solutions, S-20 analyzing or evaluating actions or policies, S-21 reading critically: clarifying or critiquing texts, S-22 listening critically: the art of silent dialogue, S-23 making interdisciplinary connections, S-24 practicing Socratic discussion: clarifying and questioning beliefs, theories, or perspectives, S-25 reasoning dialogically: comparing perspectives, interpretations, or theories, and S-26 reasoning dialectically: evaluating perspectives, interpretations, or theories

Cognitive Strategies - Micro-Skills comprise 9 strategies. Those strategies are S-27 comparing and contrasting ideals with actual practice, S-28 thinking precisely about thinking: using critical vocabulary, S-29 noting significant similarities and differences, S-30 examining or evaluating assumptions, S-31 distinguishing relevant from irrelevant facts, S-32 making plausible inferences, predictions, or interpretations, S-33 giving reasons and evaluating evidence and alleged facts, S-34 recognizing contradictions, and S35 exploring implications and consequences 


\section{Steps for critical thinking teaching}

There are many constraints in language teaching (and teaching in general), such as teacher's assumption that students cannot learn the subject at hand unless the teacher covers it. Hence, teachers must give up the belief and start active learning. This learning can make the course enjoyable and can encourage students to think critically. In addition, Bloom,s taxonomy facilitates teachers to classify instructional activities as they advance in difficulties (Duron, Limbach, and Waugh, 2006)

Figure 1

5-Step Model to Move Students toward Critical Thinking (Duron, Limbach, Waugh, 2006)

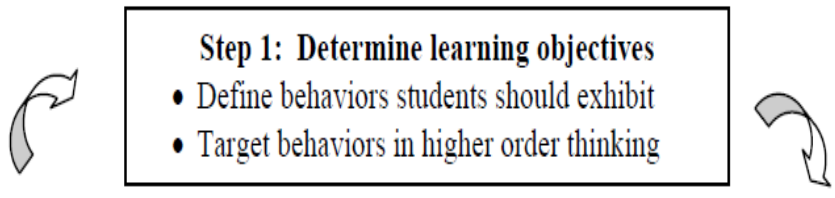

Step 5: Provide feedback and assessment of learning

- Provide feedback to students

- Create opportunities for self-assessment

- Utilize feedback to improve instruction

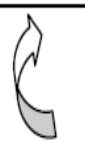

Step 4: Review, refine, and improve

- Monitor class activities

- Collect feedback from students
Step 2: Teach through questioning

- Develop appropriate questions

- Employ questioning techniques

- Encourage interactive discussion

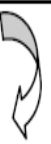

Step 3: Practice before you assess

- Choose activities that promote active learning

- Utilize all components of active learning 


\section{Designing lesson plan}

Indonesian Government Regulation No.19 of 2005 on national educational standards, article 19 paragraphs 1 tells that teaching learning process is characterized with interactive, inspiring, fun, challenging, and active learning. It means that this regulation gives space for critical thinking. Interactive and active learning such as discussion includes critical thinking strategies, such as S-33 Giving Reasons and Evaluating Evidence and Alleged Facts. This strategy can make students insightfully discuss evidence relevant to the issue and conclusions they consider (Paul, Richard W. Binker, A.J.A. and Weil, Daniel, 1995). Hence, the following discussions incorporate critical thinking into lesson plan. The format is from American English Institute, University of Oregon: Critical Thinking. The writer adds assessment row to this table. The writer includes the teaching models above that employ questioning, self and peer assessment, and teacher assessment in the lesson plan.

\section{Lesson Plan}

\begin{tabular}{|c|c|c|}
\hline Instructor: & Course: & $\begin{array}{l}\text { Student Age/Level: } 19- \\
25 \text { / intermediate }\end{array}$ \\
\hline $\begin{array}{l}\text { Title of Lesson: Writing } \\
\text { Research Background of } \\
\text { Classroom Action } \\
\text { Research }\end{array}$ & $\begin{array}{l}\text { Number of } \\
\text { Students: } 30\end{array}$ & $\begin{array}{l}\text { Length of lesson: } 100 \\
\text { minutes }\end{array}$ \\
\hline \multicolumn{3}{|c|}{$\begin{array}{l}\text { I. Overarching goal of the lesson: } \\
\text { After attending this class, students are able to understand how to write } \\
\text { research background effectively }\end{array}$} \\
\hline
\end{tabular}




\section{Prerequisites.}

At the beginning of this lesson, students are expected: (1) to have intermediate level of English; (2) to have completed their field work as English teachers in junior or senior high school; (3) to have passed research methodology class and methodology of language teaching.

\begin{tabular}{|c|c|c|}
\hline $\begin{array}{l}\text { III. Instructional Objectives for the } \\
\text { lesson: }\end{array}$ & $\begin{array}{l}\text { Bloom's domain } \\
\text { and level }\end{array}$ & CT Strategy \\
\hline $\begin{array}{l}\text { 1. Working in group of } 3 \text { to } \\
\text { read and discuss given } \\
\text { examples of good research } \\
\text { background (the condition), } \\
\text { the students (the audience) } \\
\text { will identify components or } \\
\text { information that should be } \\
\text { in a research background } \\
\text { (The behaviour) accurately } \\
\text { in four sentences (the } \\
\text { degree of accuracy) }\end{array}$ & $\begin{array}{l}\text { - } \text { Cognitive, } \\
\text { Analysis } \\
\text { Level } \\
\text { - } \text { Affective, } \\
\text { Responding } \\
\text { to } \\
\text { phenomena }\end{array}$ & $\begin{aligned} &- \text { S-21 reading } \\
& \text { critically } \\
&- \text { S-32 making } \\
& \text { plausible } \\
& \text { interpretatio } \\
& \mathrm{ns} \\
&- \text { S-1 Thinking } \\
& \text { Independentl } \\
& \text { y }\end{aligned}$ \\
\hline $\begin{array}{l}\text { 2. Given questions about } \\
\text { research background, the } \\
\text { students will write outline } \\
\text { of research background } \\
\text { accurately based on } \\
\text { components or information } \\
\text { got in phase } 1 \text { activities }\end{array}$ & $\begin{array}{l}\text { Cognitive, } \\
\text { synthesis }\end{array}$ & $\begin{array}{l}\text { S-33 Giving } \\
\text { Reasons and } \\
\text { Evaluating } \\
\text { Evidence and } \\
\text { Alleged Facts }\end{array}$ \\
\hline & & \\
\hline
\end{tabular}


III. Lesson Description

1. Pre teaching [15 minutes]

- Teacher introduces the topic

- Teacher introduce the topic through questioning

a. What do you know about research background?

b. Have you ever written research background?

2. Brainstorming and Discussion [70 minutes]

Phase 1

Teacher gives examples of research background to students. The students work in group of 3 to discuss and restate components or information that should be written in a research background. They discuss the following questions:

a. What is each paragraph mainly discussed?

b. Each paragraph informs the components of research background, what are they?

After discussing the questions, each group, then, presents the conclusions and get feedback from other groups. The next step is the teacher's feedback.

Phase 2

- Students work individually. This phase will explore individual experience during their field work. If necessary, they may share their experiences with their friends but they have to submit the result individually. The outcome is an outline of a research background. The students may refer to the previous discussion. 
- In writing their outline, The students answer the questions as a guidance:

- What is the biggest problem or the most urgent problem faced by students to solve? Could you provide data or information? (the problems and data should be based on your class during your field work)

-What is/are the cause(s) of the problem?

- What is the possible solution for the problem? What is your rationale?

Phase 3

- Students share their outline with their classmates to get feedback Phase 4

- Teacher provides feedback to students

\section{Assignment / Homework}

- Write a background of classroom action research based on the outline!

\begin{tabular}{|l|l|}
\hline \multicolumn{1}{|c|}{ IV. Assessment } & \multicolumn{1}{|c|}{ Description of CT Assessments } \\
\hline $\begin{array}{l}\text { Formative } \\
\text { Observation }\end{array}$ & $\begin{array}{l}\text { Teacher walks around the class to observe } \\
\text { and check students' understanding while } \\
\text { they are doing class assignments }\end{array}$ \\
Short response & $\begin{array}{l}\text { Teacher gives some questions, e.g. to find } \\
\text { out English teaching problems and students } \\
\text { write the answer in a paragraph }\end{array}$ \\
Summative & $\begin{array}{l}\text { Students write an essay, e.g. research } \\
\text { proposal }\end{array}$ \\
\hline
\end{tabular}


The first few lines of lesson plan are class identities comprising instructor's name, title of course, students' age/ level, title of lesson, number of students, and length of lesson. It will inform three things: teacher, students, and course.

The first part is goal of the lesson. Goal and objective refers to the same thing, outcomes. However, goal refers to general outcome while objective is more specific. Objective refers to performance students will acquire in the end of the class.

The next part is prerequisites. These are assumptions teachers are making about students' skills, knowledge, and experience for this lesson. This is requirements students need to fulfill in order to be able to complete the lesson.

The third part is instructional objectives. Heinich and his colleagues (2002 in O'Bannon. 2002) suggest four parts of well written objectives or usually called as the ABCD's of instructional objectives. The $\mathbf{A}$ stands for Audience. It is "the learner" or "the student" or as specific as "the third grade science student". The B represents Behavior. It is the verb describing the competency that the student will be able to perform after the instruction. It must be measurable, observable, and specific. The $\mathbf{C}$ stands for Condition or the circumstances under which the objectives must be completed. The last is $\mathbf{D}$ or Degree of Accuracy. It is the standard that the learner must meet to reach acceptable performance.

The fourth part is lesson description. This may include pre-, during, and post-activities, steps, or techniques that the students are doing. 


\section{Assessment}

There are two types of assessment: formative and summative assessment. Garrison and Ehringhaus (2007) explain the differences. The first assessment is part of instructional process. It informs both students and teacher about students understanding at a point. Because it can be incorporated into classroom practice, it can be used to adjust teaching and learning while they are happening.

Meanwhile formative assessment are conducted during class practice, summative are given periodically at a particular point in time, such as after instruction every few weeks, moths, semester, or once a year. It can be in form of state assessment, semester test, chapter test, etc. It can be tools to evaluate the effectiveness of programs, schools improvement goals, alignment of curriculum, or student's placement in specific program.

Furthermore, Garrison and Ehringhaus (2007) give some of the instructional strategies that can be used formatively. The first is observations. In this assessment, teacher goes beyond walking around the room to check student's work. The teacher may give feedback when he/she finds student who need clarification. The second is questioning strategies that should be embedded in lesson/unit planning. It may allows an opportunity for deeper thinking and inform teacher the degree and depth of understanding. The third is self and peer assessment. This assessment allows student to assess his/her or his/her friend works. It may helps to create a learning community within a classroom.

Other sample assessments are multiple choice, constructed response (jigsaw, fill in the blank, and matching), short response (sentence to a paragraph), extended response (essay or oral presentation), process 
performance (showing classmates how to do something, for ex. baking a cake, assembling an airplane), project performance, portfolio, interview (oral performance: discussion, impromptus, debate), assessment Rubric.

\section{Conclusion}

Critical thinking is a process of thinking involving reasoning as the basic for action. The process follows self assessment as proposed by Paul and Elder (2010): clarity, accuracy, precision, relevance, depth, breadth, logic, and fairness. These standards comprise questions that can be applied in classes of instructional to train critical thinking to students.

Critical thinking can be applied in language classes and employ Bloom's Taxonomy and Critical Thinking Strategy as working definition. In designing lesson plan, there should be: course identity, goal and objectives of lesson, prerequisites, lesson description, and assessment. In writing objectives, ABCD model can become the guidance and it should also includes Bloom's Taxonomy and critical thinking strategies. In addition, lesson description discusses pre, during, and after classes.

\section{References}

Carr, Kathryn S. 1990. How Can We Teach Critical Thinking? Retrieved 27 October 2011 from http://www.ericdigests.org/pre-9218/critical.htm

Clark, D. R. 2004. Bloom's Taxonomy of Learning Domains. Retrieved Dec 8, 2011 from http://www.nwlink.com/ donclark/hrd/bloom.html

Duron, Robert. Limbach, Barbara and Waugh, Wendy. 2006. Critical Thinking for Any Discipline. International Journal of Teaching and Learning in Higher Education 2006, Volume 17, Number 2, 160-166 
Garrison, C., \& Ehringhaus, M. (2007). Formative and summative assessments in the classroom. Retrieved from http://www.nmsa.org/Publications/WebExclusive/Assessment/tabid/1120 /Default.aspx

Hunter, David A. 2009. A Practical Guide To Critical Thinking: Deciding What to Do and Believe. New Jersey: John Wiley \& Sons, Inc

Moore, Brooke Noel and Parker, Richard. 2009. Critical Thinking. New York: McGrow-Hill Higher education

O'Bannon, B. 2002. How do I write an instructional objective? Retrieved October 20, 2011 from http://edtech.tennessee.edu/ bobannon/writing_objectives.html

Paul, R. and Elder, L.2010. Foundation For Critical Thinking, online at website: www.criticalthinking.org

Paul, Richard W. Binker, A.J.A. and Weil, Daniel. 1995. Strategy List: 35 Dimensions of Critical Thought. Retrieved October 22, 2011 from http://www.criticalthinking.org/pages/strategy-list-35-dimensions-ofcritical-thought/466

Rear, David. 2010. A Systematic Approach to Teaching Critical Thinking through Debate. Journal Eltwo, volume 2. 